\title{
EFFICACY OF METRIFONATE IN A HIGHLY ENDEMIC AREA OF URINARY SCHISTOSOMIASIS IN KENYA
}

\author{
KATSUYUKI SATO, ${ }^{*}$ MASAAKI SHIMADA, ${ }^{*}$ SHINICHI NODA, $\dagger$ \\ NGETHE D. MUHOHO,‡ TATSUYA KATSUMATA,* \\ ATSUO SATO, $†$ AND YOSHIKI AOKI* \\ *Department of Parasitology, Institute of Tropical Medicine, Nagasaki University, Japan, \\ †Department of Medical Zoology, Faculty of Medicine, Kagoshima University, Japan, and \\ $\ddagger$ Centre for Microbiology Research, Kenya Medical Research Institute, Ministry of Health, Kenya
}

Abstract. In a community in Kwale district, Kenya, selective mass chemotherapy with metrifonate caused a marked reduction in the intensity of Schistosoma haematobium infection from 46.5 to $9.4 \mathrm{eggs} / \mathrm{hr}$ and a sharp fall in prevalence of gross hematuria from $18.3 \%$ to $5.1 \%$, although overall prevalence was reduced only slightly from $67.4 \%$ to $54 \%$. The effect of metrifonate on cure rate and reduction of infection intensity was limited by both age and pretreatment infection intensity. Rate of improvement from gross hematuria was similar in all ages and in all classes of intensity of infection. Two doses of metrifonate reduced the prevalence of gross hematuria as much as 3 doses did, while the effect of a single dose on morbidity remains to be clarified.

Chemotherapy is playing an increasing role in the control of schistosomiasis and also acts directly as a disease control agent.' Thus, the assessment of control programs should include the impact on morbidity. ${ }^{2}$

Metrifonate has been used in selective mass chemotherapy programs for urinary schistoso-

Accepted 16 July 1987. miasis because it is effective, inexpensive, and has few side effects. ${ }^{1}$ This study was designed to assess its effectiveness against Schistosoma haematobium infection at the community level by using quantitative parasitological techniques and by assessing gross hematuria. We also describe the effectiveness of single and double doses of metrifonate on cure rate, reduction of infection intensity, and prevalence of gross hematuria.

TABLE 1

Prevalence, intensity of infection, and frequency of gross hematuria of urinary schistosomiasis before and after selective mass chemotherapy

\begin{tabular}{|c|c|c|c|c|c|c|c|c|c|c|}
\hline & \multicolumn{9}{|c|}{ Age group } & \multirow[b]{2}{*}{ Total } \\
\hline & $0-4$ & $5-9$ & $10-14$ & $15-19$ & $20-29$ & $30-39$ & $40-49$ & $50-59$ & $\geq 60$ & \\
\hline \multicolumn{11}{|l|}{ Pretreatment } \\
\hline No. examined & 103 & 136 & 103 & 49 & 77 & 65 & 46 & 51 & 47 & 677 \\
\hline $\begin{array}{l}\text { No. }(\%) \text { of egg posi- } \\
\text { tives }\end{array}$ & $\begin{array}{l}27 \\
(26.2)\end{array}$ & $\begin{array}{l}91 \\
(66.9)\end{array}$ & $\begin{array}{l}97 \\
(94.2)\end{array}$ & $\begin{array}{l}44 \\
(89.8)\end{array}$ & $\begin{array}{l}62 \\
(80.5)\end{array}$ & $\begin{array}{l}46 \\
(70.8)\end{array}$ & $\begin{array}{l}33 \\
(71.7)\end{array}$ & $\begin{array}{l}33 \\
(64.7)\end{array}$ & $\begin{array}{l}23 \\
(48.9)\end{array}$ & $\begin{array}{l}456 \\
(67.4)\end{array}$ \\
\hline $\begin{array}{l}\text { Eggs/hour (geomet- } \\
\text { ric mean) }\end{array}$ & 3.1 & 51.1 & 925.5 & 215.0 & 90.1 & 22.6 & 35.5 & 12.7 & 9.4 & 46.5 \\
\hline $\begin{array}{l}\text { No. }(\%) \text { with hema- } \\
\text { turia }\end{array}$ & $\begin{array}{l}6 \\
(5.8)\end{array}$ & $\begin{array}{l}21 \\
(15.4)\end{array}$ & $\begin{array}{l}50 \\
(48.5)\end{array}$ & $\begin{array}{l}17 \\
(34.7)\end{array}$ & $\begin{array}{l}11 \\
(14.3)\end{array}$ & $\begin{array}{c}9 \\
(13.8)\end{array}$ & $\begin{array}{c}7 \\
(15.2)\end{array}$ & $\begin{array}{l}2 \\
(3.9)\end{array}$ & $\begin{array}{l}1 \\
(2.1)\end{array}$ & $\begin{array}{l}124 \\
(18.3)\end{array}$ \\
\hline \multicolumn{11}{|l|}{ Post-treatment } \\
\hline No. examined & 64 & 158 & 128 & 89 & 80 & 61 & 46 & 51 & 49 & 726 \\
\hline $\begin{array}{l}\text { No. (\%) of egg posi- } \\
\text { tives }\end{array}$ & $\begin{array}{l}28 \\
(43.8)\end{array}$ & $\begin{array}{l}95 \\
(60.1)\end{array}$ & $\begin{array}{l}101 \\
(78.9)\end{array}$ & $\begin{array}{l}54 \\
(60.7)\end{array}$ & $\begin{array}{l}42 \\
(52.5)\end{array}$ & $\begin{array}{l}19 \\
(31.1)\end{array}$ & $\begin{array}{l}25 \\
(54.3)\end{array}$ & $\begin{array}{l}16 \\
(31.4)\end{array}$ & $\begin{array}{l}12 \\
(24.5)\end{array}$ & $\begin{array}{l}392 \\
(54.0)\end{array}$ \\
\hline $\begin{array}{l}\text { Eggs/hour (geomet- } \\
\text { ric mean) }\end{array}$ & 1.7 & 20.3 & 61.6 & 30.2 & 6.1 & 1.8 & 3.4 & 2.1 & 1.2 & 9.4 \\
\hline $\begin{array}{l}\text { No. (\%) with hema- } \\
\text { turia }\end{array}$ & $\begin{array}{l}1 \\
(1.6)\end{array}$ & $\begin{array}{l}7 \\
(4.4)\end{array}$ & $\begin{array}{l}13 \\
(10.2)\end{array}$ & $\begin{array}{c}9 \\
(10.1)\end{array}$ & $\begin{array}{l}3 \\
(3.8)\end{array}$ & $\begin{array}{l}1 \\
(1.6)\end{array}$ & $\begin{array}{l}3 \\
(6.5)\end{array}$ & 0 & 0 & $\begin{array}{l}37 \\
(5.1)\end{array}$ \\
\hline
\end{tabular}


TABLE 2

Effect of dosage on parasitological cure rate and reduction in intensity of infection

\begin{tabular}{lccccc}
\hline & \multicolumn{2}{c}{ Cure rate (\%) } & & \multicolumn{2}{c}{ Geometric mean egg count } \\
\cline { 2 - 3 } \cline { 5 - 6 } Dosage (7.5 mg/kg) & No. subjects & No. cured & & Pretreatment & $\begin{array}{c}\text { Post-treatment } \\
(\% \text { reduction) }\end{array}$ \\
\hline Single dose & 30 & $7(23.3)$ & & 217.0 & $42.3(80.5)$ \\
Two doses & 69 & $21(30.4)$ & & 508.8 & $23.5(95.4)$ \\
Three doses & 237 & $91(38.4)$ & & 392.7 & $14.0(96.4)$ \\
\hline
\end{tabular}

MATERIALS AND METHODS

\section{Study area and population}

The study was conducted in Kenya at Mwachinga village, Kwale district, an area known to be highly endemic for urinary schistosomiasis. ${ }^{3}$ The number of residents registered at the 1982 census was 1,338 (617 males and 721 females). About half of the people were under 15 years of age.

\section{Urine examination}

Pretreatment urine examination was done in December 1983. Urine was collected $1 \mathrm{hr}$ after the previous urination during mid-day. The intensity of infection was expressed as the number of eggs excreted per $1 \mathrm{hr}$ assessed by the filtration method of Peters. ${ }^{4}$ The rationale for this method has been published elsewhere. ${ }^{5}$ The geometric mean was obtained by using the $n+1$ transformation for a series of egg outputs including zeros. The appearance of urine was classified as yellow, brown (bloody), or red (very bloody). Bloody urine was used as a morbidity indicator, because it is a simple, specific, and sensitive indicator of infection. ${ }^{6}$

\section{Selective mass chemotherapy}

Treatment was given in February and March 1984 and effectiveness was evaluated 4 months later. Subjects passing eggs at least once in 4 previous examinations (June and December 1982, June and December 1983) and all children 5-15 years old were treated. Metrifonate was scheduled to be given 3 times at a dose of 7.5 $\mathrm{mg} / \mathrm{kg}$ body weight at 2 -week intervals. ${ }^{7}$

\section{RESULTS}

Post-treatment prevalence and intensity of infection, and frequency of gross hematuria

Urine specimens of 677 villagers were examined. Prevalence and intensity of infection and frequency of hematuria showed similar patterns of variance with age, all increasing rapidly to the 10-14 year group, followed by a steady decline in adults (Table 1). Overall prevalence of hematuria was $18.3 \%$, with $5 \%(34 / 677)$ having very bloody urine.

Out of 813 subjects qualifying for treatment, 690 took metrifonate: in a single dose $(n=118)$, 2 doses $(n=159)$, and 3 doses $(n=413)$.

Four months later, 726 villagers were examined for eggs and urine color. The results are

TABLE 3

Effect of dosage on reduction in prevalence of gross hematuria

\begin{tabular}{|c|c|c|c|c|c|c|c|c|}
\hline & \multirow[b]{2}{*}{$\begin{array}{l}\text { No. } \\
\text { examined }\end{array}$} & \multicolumn{2}{|c|}{$\begin{array}{l}\text { No. with hematuria } \\
\text { (No. with red urine) }\end{array}$} & \multicolumn{5}{|c|}{$\begin{array}{l}\text { Presence or absence of hematuria } \\
\text { pre- and post-treatment }\end{array}$} \\
\hline & & $\begin{array}{c}\text { Pre- } \\
\text { treatment }\end{array}$ & $\begin{array}{c}\text { Post- } \\
\text { treatment }\end{array}$ & $\begin{array}{l}\text { (Pre-) } \\
\text { (Post-) }\end{array}$ & $\begin{array}{l}+ \\
+\end{array}$ & $\begin{array}{l}+ \\
-\end{array}$ & $\overline{-}$ & $\overline{+}$ \\
\hline $\begin{array}{l}\text { Single dose } \\
\text { Two doses } \\
\text { Three doses }\end{array}$ & $\begin{array}{r}30 \\
67 \\
232\end{array}$ & $\begin{array}{r}6(2) \\
20(8) \\
73(2)\end{array}$ & $\begin{array}{r}4(0) \\
4(0) \\
10(2)\end{array}$ & & $\begin{array}{l}3 \\
4 \\
9\end{array}$ & $\begin{array}{r}3 \\
16 \\
64\end{array}$ & $\begin{array}{r}23 \\
47 \\
158\end{array}$ & $\begin{array}{l}1 \\
0 \\
1\end{array}$ \\
\hline Total & 329 & 99 (12) & $18(2)$ & & 16 & 83 & 228 & 2 \\
\hline
\end{tabular}


TABLE 4

Parasitological cure rate of patients given 3 doses of metrifonate at $7.5 \mathrm{mg} / \mathrm{kg}$ body weight by sex, age, and intensity of infection

\begin{tabular}{lccc}
\hline \multicolumn{1}{c}{ Patients } & $\begin{array}{c}\text { No. } \\
\text { examined }\end{array}$ & No. cured & Rate (\%) \\
\hline Male & 108 & 36 & 33.3 \\
Female & 129 & 55 & 42.6 \\
×14 years & 122 & 25 & 20.5 \\
$\geq 15$ years & 115 & 66 & 57.4 \\
Intensity of infection & & & \\
$\quad<10$ & 20 & 14 & 70.0 \\
$\quad 10-99$ & 44 & 20 & 45.5 \\
$100-999$ & 87 & 41 & 47.1 \\
$\geq 1,000$ & 86 & 16 & 18.6 \\
\hline
\end{tabular}

shown in Table 1. Mass chemotherapy caused a sharp fall in the intensity of infection, though the overall prevalence was only slightly reduced. Prevalence of hematuria was reduced to less than one third of the pretreatment level, and red urine was observed in only $0.8 \%$ of the specimens.

Cure rate, reduction in egg output, and gross hematuria in relation to dosage

Among those treated with metrifonate, 336 individuals underwent both pre- and post-treatment urine examinations ( 7 samples were not examined for color due to an oversight). Results are shown in Tables 2 and 3. The cure rate and percent reduction of mean egg output were significantly lower in the groups with fewer doses $(P<0.01)$. However, reduction of hematuria was not significantly different between the 2-dose and 3 -dose groups (Yates' correction, $P>0.5$ ). It was not possible to assess precisely the efficacy of a single dose on hematuria because the number of
TABLE 6

Reduction in intensity of infection of patients receiving 3 doses of metrifonate

\begin{tabular}{lcccc}
\hline & & \multicolumn{2}{c}{ Geometric mean egg count } \\
\cline { 3 - 4 } & $\begin{array}{l}\text { No. } \\
\text { sub- } \\
\text { jects }\end{array}$ & $\begin{array}{c}\text { Pre- } \\
\text { treat- } \\
\text { ment }\end{array}$ & $\begin{array}{c}\text { Post- } \\
\text { treat- } \\
\text { ment }\end{array}$ & $\begin{array}{c}\text { \% re- } \\
\text { duction }\end{array}$ \\
\hline Male & 108 & 487.6 & 18.5 & 96.2 \\
Female & 129 & 327.5 & 11.1 & 96.6 \\
$\leq 14$ years & 122 & 879.8 & 52.8 & 94.0 \\
$\geq 15$ years & 115 & 166.5 & 2.9 & 98.3 \\
\hline
\end{tabular}

subjects with hematuria in this group was very small (Table 3).

Cure rate in relation to sex, age, and intensity of infection

Table 4 shows the cure rate among subjects receiving 3 doses of metrifonate. Cure rate was not influenced by sex, but varied with age and intensity of infection, being significantly lower in children $(<14$ years) than in adults ( $>14$ years) $(P<0.001)$. Those with lower egg counts had a higher cure rate than those with initially higher egg counts $(P<0.001)$.

Table 5 compares the cure rate of children and adults who had the same level of infection intensity. At higher levels of infection, metrifonate was still less effective in children than adults $(P<$ $0.05, \chi^{2}$ statistic).

\section{Reduction of egg output in relation to sex, age, and intensity of infection}

Table 6 shows the geometric mean of egg count among subjects who completed 3 doses of metrifonate. Sex did not affect reduction in egg count,

TABLE 5

Comparison of parasitological cure rate after 3 doses of metrifonate between children and adults showing the same level of intensity of infection

\begin{tabular}{|c|c|c|c|c|c|c|}
\hline \multirow[b]{2}{*}{ Age } & & \multicolumn{5}{|c|}{ Geometric mean egg count } \\
\hline & & $<10$ & $10-99$ & $100-999$ & $\geq 1,000$ & Total \\
\hline$\leq 14$ years & $\begin{array}{l}\text { No. subjects } \\
\text { No. cured } \\
\text { Cure rate }(\%)\end{array}$ & $\begin{array}{c}6 \\
3 \\
50.0\end{array}$ & $\begin{array}{l}12 \\
2 \\
16.7^{*}\end{array}$ & $\begin{array}{l}42 \\
12 \\
28.6^{*}\end{array}$ & $\begin{array}{l}62 \\
8 \\
12.9^{*}\end{array}$ & $\begin{array}{l}122 \\
25 \\
20.5\end{array}$ \\
\hline$\geq 15$ years & $\begin{array}{l}\text { No. subjects } \\
\text { No. cured } \\
\text { Cure rate (\%) }\end{array}$ & $\begin{array}{l}14 \\
11 \\
78.6\end{array}$ & $\begin{array}{l}32 \\
18 \\
56.3\end{array}$ & $\begin{array}{l}45 \\
29 \\
64.4\end{array}$ & $\begin{array}{c}24 \\
8 \\
33.3\end{array}$ & $\begin{array}{c}115 \\
66 \\
57.4\end{array}$ \\
\hline
\end{tabular}

* Cure rates of children were significantly less than those of adults in each level of intensity of infection $\left(P<0.05, x^{2}\right.$ statistic). 
TABLE 7

Comparison of reduction in egg count between children and adults showing the same level of intensity of infection

\begin{tabular}{clccccc}
\hline & & \multicolumn{4}{c}{ Geometric mean egg count } \\
\cline { 3 - 6 } Age & & $<10$ & $10-99$ & $100-999$ & $\geq 1,000$ & Total \\
\hline$\leq 14$ years & Pretreatment & 4.6 & $40.1^{*}$ & $388.6^{*}$ & $4,521.9^{*}$ & 879.8 \\
& Post-treatment & $2.6(6)$ & $57.4(12)$ & $20.8(42)$ & $125.8(62)$ & $52.8(122)$ \\
& \% reduction & 43.3 & & 94.7 & 97.2 & 94.0 \\
$\geq 15$ years & Pretreatment & 3.7 & 35.9 & 301.5 & $3,329.5$ & 166.5 \\
& Post-treatment & $0.7(14)$ & $2.0(32)$ & $1.9(45)$ & $14.3(24)$ & $2.9(115)$ \\
& \% reduction & 81.5 & 94.4 & 99.4 & 99.6 & 98.3 \\
\hline
\end{tabular}

Number of subjects in parentheses.
After the transformation of egg count by $\log (x+1)$, differences between pre- and post-treatment were calculated and compared between adults After the transformation of $\mathrm{egg}$ count by $\log (x+1)$, differences betweet
and children.

- Differences were statistically significant. $(P<0.05$, Student's $t$-test.)

but the rate of reduction was higher in adults than in children. When adults and children were compared on the basis of intensity of infection at higher levels (Table 7), more drastic reductions again were observed in adults than in children $(P<0.05$, Student's $t$-test $)$.

\section{Reduction of prevalence of gross hematuria in} relation to sex, age, and intensity of infection

A total of 232 urine samples were analyzed, with the results shown in Table 8 . The rate of reduction in frequency of hematuria did not differ by sex, age, or intensity of infection.

\section{DISCUSSION}

The therapeutic efficacy of metrifonate has been reported by many researchers..$^{2.8-12}$ However, most of the reports have dealt exclusively with children as subjects. This study was designed to determine the therapeutic effect of metrifonate at the community level. A marked reduction in infection intensity and prevalence of gross hematuria was observed. Although our study showed only a modest cure rate, the results confirm that selective mass chemotherapy with metrifonate is an effective control strategy for morbidity due to urinary schistosomiasis.

Infection in children was less responsive to metrifonate than in adults. Lower cure rate and smaller reduction in egg output of children could be due to the age of the subjects or to higher intensity of infection. It is recognized that cure rate is greatly affected by pretreatment egg count, ${ }^{7.8 .13}$ and also that age plays an important role in the effectiveness of many drugs. ${ }^{14}$

The rate of improvement from gross hematuria was similar in all ages and in all but the lowest class of infection intensity, in which prevalence of hematuria was too low to draw a conclusion. The results suggest that morbidity in an entire community decreases homogeneously after treatment while intensity of infection remains

TABLE 8

Reduction of prevalence of gross hematuria in patients receiving 3 doses of metrifonate by sex, age, and intensity of infection

\begin{tabular}{|c|c|c|c|c|c|c|c|c|}
\hline & \multirow[b]{2}{*}{$\begin{array}{l}\text { No. } \\
\text { examined }\end{array}$} & \multicolumn{2}{|c|}{ No. with hematuria } & \multicolumn{5}{|c|}{$\begin{array}{l}\text { Presence or absence of hematuria } \\
\text { at pre- and post-treatment }\end{array}$} \\
\hline & & $\begin{array}{c}\text { Pre- } \\
\text { treatment }\end{array}$ & $\begin{array}{c}\text { Post- } \\
\text { treatment }\end{array}$ & $\begin{array}{l}\text { (Pre-) } \\
\text { (Post-) }\end{array}$ & $\begin{array}{l}+ \\
+\end{array}$ & \pm & - & $\overline{+}$ \\
\hline $\begin{array}{l}\leq 14 \text { years } \\
\geq 15 \text { years }\end{array}$ & $\begin{array}{l}120 \\
112\end{array}$ & $\begin{array}{l}49 \\
24\end{array}$ & $\begin{array}{l}8 \\
2\end{array}$ & & $\begin{array}{l}7 \\
2\end{array}$ & $\begin{array}{l}42 \\
22\end{array}$ & $\begin{array}{l}70 \\
88\end{array}$ & $\begin{array}{l}1 \\
0\end{array}$ \\
\hline $\begin{array}{l}\text { Male } \\
\text { Female }\end{array}$ & $\begin{array}{l}107 \\
125\end{array}$ & $\begin{array}{l}33 \\
40\end{array}$ & $\begin{array}{l}5 \\
5\end{array}$ & & $\begin{array}{l}4 \\
5\end{array}$ & $\begin{array}{l}29 \\
35\end{array}$ & $\begin{array}{l}73 \\
85\end{array}$ & $\begin{array}{l}1 \\
0\end{array}$ \\
\hline \multicolumn{9}{|c|}{ Intensity of infection } \\
\hline $\begin{array}{c}<100 \\
100-999 \\
\geq 1,000\end{array}$ & $\begin{array}{l}63 \\
85 \\
84\end{array}$ & $\begin{array}{r}3 \\
20 \\
50\end{array}$ & $\begin{array}{l}2 \\
2 \\
6\end{array}$ & & $\begin{array}{l}2 \\
2 \\
5\end{array}$ & $\begin{array}{r}1 \\
18 \\
45\end{array}$ & $\begin{array}{l}60 \\
65 \\
33\end{array}$ & $\begin{array}{l}0 \\
0 \\
1\end{array}$ \\
\hline
\end{tabular}


heterogeneous. The improvement of gross hematuria using the 3-dose regimen is comparable to results obtained using praziquantel in Lake Volta, Ghana. ${ }^{15}$

Efficacy of metrifonate has been reported to be dose-dependent. ${ }^{7}$ This was confirmed by the cure rate and reduction in intensity of infection in our study. The cure rate by 3 doses in our study is lower than that reported from other endemic areas, ${ }^{8.9}$ which might be due to either variances in infection intensity or to a difference in schistosome susceptibility to metrifonate, as has been suggested by Wilkins and Moore. ${ }^{1}$

A single dose of metrifonate showed comparatively marked reduction in urine egg count. ${ }^{10,12}$ Three out of 6 subjects with hematuria at pretreatment were negative and without red urine at post-treatment examination after a single dose. This indicates a promising effect of single-dose metrifonate on morbidity due to $S$. haematobium infection. Two doses of metrifonate reduced prevalence of gross hematuria similarly to 3 doses; therefore a 2-dose regimen is recommended and expected to increase compliance, as it did in our study by $20 \%$.

\section{ACKNOWLEDGMENTS}

We are indebted to $M$. Mugambi, Director of the Kenya Medical Research Institute, and T. K. Arap Siongok, Director of the Division of Communicable Diseases Control, for their permission and encouragement in conducting this study. We are also grateful to the staff of the Division of Vector-Borne Diseases in Kwale and the staff of Kinango Hospital for their cooperation during the survey. The authors wish to thank Y. Nakajima of Yamanashi Medical College for his editorial suggestions.

This study was supported by the Kenya Medical Research Institute, Ministry of Health, Kenya, and the Japan International Cooperation Agency, Japan.

\section{REFERENCES}

1. World Health Organization, 1985. The control of schistosomiasis. Report of a WHO Expert Committee. WHO Tech. Rep. Ser. No. 728.

2. Kholy, A. E., Boutros, S., Tamara, F., Warren, K.
S., and Mahmoud, A. A. F., 1984. The effect of a single dose of metrifonate on Schistosoma haematobium infection in Egyptian school children. Am. J. Trop. Med. Hyg., 33: 1170-1172.

3. Highton, R. B., 1974. Schistosomiasis, Health and Disease in Kenya. Kenya Literature Bureau. p. 347.

4. Peters, P. A., 1976. Field studies of a rapid, accurate means of quantifying Schistosoma haematobium eggs in urine samples. Bull. WHO, 54: 159-162.

5. Shimada, M., Hirata, M., Sato, K., Wambayi, E., and Ouma, J., 1983. Comparison of different units of egg count in urine to determine the intensity of schistosomiasis haematobia. Proc. 4th Ann. Med. Sci. Conf., Kenya 1983. p. 332.

6. Mott, K. E., Dixon, H., Osei-Tutu, E., England, E. C., Ekue, K., and Tekle, A., 1985. Indirect screening for Schistosoma haematobium infection: A comparison study in Ghana and Zambia. Bull. WHO, 63: 135-142.

7. Davis, A., and Bailey, D. R., 1969. Metrifonate in urinary schistosomiasis. Bull. WHO, 41: 209224.

8. Reddy, S., Oomen, J. M. V., and Bell, D. R., 1975. Metrifonate in urinary schistosomiasis: A field trial in northern Nigeria. Ann. Trop. Med. Parasitol., 69: 73-76.

9. Jewsbury, J. M., Cooke, M. J., and Weber, M. C., 1977. Field trial of metrifonate in the treatment and prevention of schistosomiasis infection in man. Ann. Trop. Med. Parasitol., 71: 67-83.

10. Arap Siongok, T. K., Ouma, J. H., Houser H. B., and Warren, K. S., 1978. Quantification of infection with Schistosoma haematobium in relation to epidemiology and selective population chemotherapy. II. Mass treatment with a single oral dose of metrifonate. J. Infect. Dis., 138: 856-858.

11. Wilkins, H. A., and Moore, P. J., 1980. Single dose use of metrifonate. Trans. R. Soc. Trop. Med. Hyg., 74: 692.

12. Pugh, R. N. N., and Teesdale, C. H., 1984. Longterm efficacy of single-dose oral treatment in schistosomiasis haematobium. Trans. $R$. Soc. Trop. Med. Hyg., 78: 55-59.

13. Feldmeier, H., Doehring, E., Daffalla, A. A., Omer, A. H. S., and Dietrich, M., 1982. Efficacy of metrifonate in urinary schistosomiasis in light and heavy infections. Tropenmed. Parasit., 33: 102-106.

14. Fingl, E., and Woodbury, D. M., 1975. The Pharmacological Basis of Therapeutics. Macmillan Publishing Co., Inc., New York. 34 p.

15. Mott, K. E., Dixon, H., Osei-Tutu, E., England, E. C., and Davis, A., 1985. Effect of praziquantel on hematuria and proteinuria in urinary schistosomiasis. Am. J. Trop. Med. Hyg., 34: 1119-1126. 